\title{
Needed Help
}

National Cancer Institute

\section{Source}

National Cancer Institute. Needed Help. NCI Thesaurus. Code C107525.

The individual required assistance. 